\title{
Pentingnya Supervisi Pendidikan yang Baik untuk Menunjang Tujuan Pendidikan
}

\author{
Fitria Afifah
}

Email: fitriaafifah92@gmail.com

\begin{abstract}
ABSTRAK
pendidikan merupakan pembelajaran pengetahuan, keterampilan, dan kebiasaan sekelompok orang yang diturunkan dari satu generasi ke generasi berikutnya melalui pengajaran, pelatihan, atau penelitian. pendidikan sering sering terjadi di bawah bimbingan orang lain, namun juga bisa secara otodidak. untuk meningkatkan kualitas pendidikan yang baik perlu adanya supervisi pendidikan. supervisi pendidikan merupakan pembinaan yang berupa bimbingan atau tuntunan ke arah perbaikan situasi pendidikan pada umumnya dan meningkatkan mutu mengajar dan belajar dan belajar pada khususnya.Supervisi pendidikan adalah hal yang sangat penting dilakukan untuk menigkatkan mutu pendidikan. mutu pendidikan sangat berkaitan erat dengan keprofesionalan guru dalam menghadapi permasalahan-permasalahan yang ada di dunia pendidikan baik didunia masa kini maupun masa yang akan datang. Berdasarkan hal tersebut pendidikan merupakan faktor yang penting karena pendidikan merupakan salah-satu penentu mutu SDM (sumber daya manusia) dimana manusia dapat membina kepribadiannya dengan jalan mengembngkan potensi-potensi yang dimiliki sesuai dengan nilai-nilai yang ada dalam masyarakat. Perkembangan supervise pendidikan dewasa ini menuntut guru yang menguasai segala hal yang mencangkup supervise pendidikan, baik supervisi di bidang sarana prasarana, bidang keahlian khusus, maupun bidang pembelajaran. Karena semakin guru menguasai semua bidang supervisi pendidikan maka semakin tercapai tujuan pembelajaran yang baik. Untuk melaksanakan itu semua maka guru harus mengetahui unsur dalam supervisi pendidikan seperti unsur proses pengarahan, dan unsur- unsur guru profesionalia.
\end{abstract}

Kata Kunci : Pendidikan, Supervisi Pendidikan, Guru 


\section{BAB I \\ PENDAHULUAN}

\section{LATAR BELAKANG}

pendidikan merupakan pembelajaran pengetahuan, keterampilan, dan kebiasaan sekelompok orang yang diturunkan dari satu generasi ke generasi berikutnya melalui pengajaran, pelatihan, atau penelitian. pendidikan sering sering terjadi di bawah bimbingan orang lain, namun juga bisa secara otodidak. untuk meningkatkan kualitas pendidikan yang baik perlu adanya supervisi pendidikan. supervisi pendidikan merupakan pembinaan yang berupa bimbingan atau tuntunan ke arah perbaikan situasi pendidikan pada umumnya dan meningkatkan mutu mengajar dan belajar dan belajar pada khususnya.

Supervisi pendidikan adalah hal yang sangat penting dilakukan untuk menigkatkan mutu pendidikan. mutu pendidikan sangat berkaitan erat dengan keprofesionalan guru dalam menghadapi permasalahan-permasalahan yang ada di dunia pendidikan baik didunia masa kini maupun masa yang akan datang. Berdasarkan hal tersebut pendidikan merupakan faktor yang penting karena pendidikan merupakan salah-satu penentu mutu SDM (sumber daya manusia) dimana manusia dapat membina kepribadiannya dengan jalan mengembngkan potensi-potensi yang dimiliki sesuai dengan nilai-nilai yang ada dalam masyarakat.

Supervise pendidikan sangat diperlukan diera sekarang untuk menunjang tujuan pendidikan di Indonesia, pendidikan yang baik lahirdari supervise yangbaik. Supervise dilaksanakan oleh semua elemen sekolah, dan yang paling utama menjalankan supervise yang baik adalah guru. Bagaimana guru mengolah supervise pendidikan dalam proses belajar dan mengajar. Supervisi pendidikan berkembang seiring dengan perkembangan ilmu pengetahuan, teknologi, serta social ekonomi dan budaya masyarakat. Supervisi bergerak dari berbentuk inspeksi dimana otoritas lebih di dominasi oleh supervisor dan guru bersama berinisiatif dan bertanggung jawab dalam meningkatkan kualitas pembelajaran, serta menumb uhkan budaya belajar pada guru untuk meningkatkan potensinya. pada era sekarang supervisi kurang dijalankan dengan baik sehingga perlu pelatihan khusus agar guru menjalankan supervise pendidikan yang diharapkan untuk menunjang proses belajar mengajar yan g baik., Jadi saya membuat artikel tentang pentingnya supervise pendidikan pada masa sekarang.

\section{RUMUSKAN PERMASALAHAN}

Dari latar belakang di atas maka dirumuskan masalah (1) Apa saja yang harus dikuasai guru untuk menjalankan supervisi yang baik ? dan (2) Bagaimana implementasi pendidikan dalam meningkatkan proses pembelajaran?

\section{TUJUAN}

Tujuan dari makalah ini adalah (1)Mengetahui kinerja yang dikuasai guru untuk menjalankan supervisi yang baik. DAN (2) Mengetahui implementasi pendidikan dalam meningkatkan proses pembelajaran. 


\section{BAB II}

\section{PEMBAHASA}

Perkembangan supervise pendidikan dewasa ini menuntut guru yang menguasai segala hal yang mencangkup supervise pendidikan, baik supervisi di bidang sarana prasarana, bidang keahlian khusus, maupun bidang pembelajaran. Karena semakin guru menguasai semua bidang supervisi pendidikan maka semakin tercapai tujuan pembelajaran yang baik. Untuk melaksanakan itu semua maka guru harus mengetahui unsur dalam supervisi pendidikan seperti unsur proses pengarahan, dan unsur- unsur guru profesionalia. Selain unsur supervisi tujuan dan fungsi supervise pendidikan harus dikuasai guru juga. Supervise merupakan proses bantuan bagi guru dalam mengembangkan kemampuannya yang meliputi pengetahuan, keterampilan mengajar, dan komitmen atau motivasi guru. Jadi tujuan supervise berkenaan dengan aspek kogniktif, psikomotor dan afektif adalah membantu memperbaiki dan meningkatkan pengolahan sekolah sehingga tercapai kondisi kegiatan belajar mengajar yang sebaikbaiiknya. Sebagaimana yang dikemukakan oleh sabandi (Sabandi, 2013) Fokus perhatian supervisor adalah menemukan kesalahan guruberdasarkan standar kerja baku yang dirumuskan sedemikian rupa oleh otoritas pendidikan. Guru melaksanakan tugas sesuai dengan prosedur operasional yang standar. Supervisor dengan guru merupakan dua pihak sebagai atasan-bawahan. Supervisor memiliki tingkat kebenaran yang lebih tinggi dari pada guru.

Tujuan supervise menurut Hariwung adalah sebagai pengendalian kualitas, pengembangan professional dan untuk memotivasi guru. Supervise sebagai pengendalian kualitas artinya, kepala sebagai supervisor bertanggung jawab memonitor proses belajar mengajar disekolah dengan cara berkunjung ke kelas, berkonsultasi dengan guru yang dapat diharapkan pendidikan mampu menilai dan mengetahui kemampuan siswa.

Supervise yang baik adalah supervise yang mampu merefleksikan multi tujuan tersebut. Supervise tidalk berhasil jika hanya memperhatikan salah satu tujuan tertentu dengan mengesampingkan tujuan yang lain. Jadi dengan demikian, dapat dipahami, bahwa tujuan supervise pendidikan adalah perbaikan dan pengembangan proses belajar mengajar secara total, ini berarti tujuan supervise pendidikan tidak hanya untuk memperbaiki mutu belajar guru, tetapi juga membina pertumbuhan profesi guru dalam arti luas, termasuk di dalamnya pengadaan fasilitas-fasilitas, pelayanan kepemimpinan dan pembinaan hubungan yang baik kepada semua pihak yang terkait.

Adapun kinerja lain yang harus dikuasai guru antara lain adalah menguasai fungsi dari supervise pendidikan :

1. Fungsi penelitian, fungsi ini ini bertujuan guna mendapatkan gambaran yang jelas dan objektif tentang situasi pendidikan.

2. Fungsi penilaian, fungsi ini merujuk kepada evaluasi hasil penelitian yang telah dilakukan sebelumnhya.

3. Fungsi perbaikan, fungsi ini merupakan kelanjutan dari fungsi penilaian. Bermakna bahwa ketika penelitian menunjukan hasil yang rendah maka 
diperlukan perbaikan dalam kegiatan supervise.

4. Fungsi peningkataan, fungsi ini lebih mengacu pada hasil penelitian, yang menunjukan hasil positif,artinya pelaksanaan kegiatan supervises perlu ditingkatkan secara berkesinabungan dan terarah. Sehingga tujuan pelaksanaan kegiatan supervise dapat dicapai dengan maksimal.

Implementasi supervise pendidikan dalam meningkatkan proses pembelajaran adalah dengan perbaikan proses pembelajaran dengan membantu guru merencanakan program akademis, dan pengembangan profesi dalam melaksanakan program pengajaran. Kemampuan dalam proses belajar mengajar guru disekolah adalah penguasaan materi atau bahan, jika guru menguasai materi dan bahan yang akan diajarkan kepada peserta didik, maka guru telah mampu mengimplementasikan supervise dalam proses belajar mengajar yang baik dan benar.

Guru sebagai pendidik tidak hanya brkenaan dengan prosess penyampaian ilmu pengetahuan tetapi menya ngkut juga pengembangan kepribadian siswa, pembentukan nilai-nilai etika siswa yang menghadapi tantangan kehidupan masyarakat, dan guru juga mengimplementasikan semua aspek supervise pendidikan tidak hanya untuk siswa, tetapi juga untuk pengembangan profesi guru untuk menjadiu guru yang lebih baik.

Jika supervise pendidikan telah di implementasikan dengan baik dan benar dalam pendidikan maka tujuan pendidikan akan tercapai dengan baik, siswa tidak hanya mendapatkan ilmu pengetahuan saja tetapi juga bekal untuk kehidupan bermasyarakat, dimana kita tahu bhawa tujuan dari pendidikan Indonesia adalah mencerdaskan kehidupan bangsa, tidak hanya cerdas ilmu pengetahuan tetapi juga ilmu social untuk bekal kehidupan bermasyarakat setelah tamat pada pendidikan formal. Selain itu profesi guru untuk menjadi guru yang professional juga akan semakin berkembang dengan menjalankan supervise pendidikan yang baik dan benar.

\section{KESIMPULAN}

Supervise pendidikan adalah pedoman guru dalam melkasankan proses belajar dan mengajar, tidak hanya untuk guru tetapi juga untuk siswa agarprofesi guru dan ilmu pengatahuan siswa dapat dikembangkan. Dengan supervise pendidikan membantu guru dalam melaksanakan tugasnyha mencapai tujuan pendidikan Indonesia yang baik dan benar. Jadi dapat ditarik kesimpulan bahwa supervise pedidikan sangat membantuguru dalam menjalankan tugasnya sehingga guru juga professional dalam melaksanakan profesi yang diembannya. 


\section{REFERENSI}

Sabandi, A. (2013). Supervisi Pendidikan Untuk Pengembangan Profesionalitas Guru

Supervisi Pendidikan Untuk Pengembangan Profesionalitas Guru Berkelanjutan

Oleh: Pedagogi, Junal IImiah IImu Pendidikan, XVII(2), 1-9. Retrieved from

http://ejournal.unp.ac.id/index.php/pedagogi/article/view/4275/3345

Suryan, Cut. (2015). Implementasi Supervisi Pendidikan Dalam Meningkatkan Proses

Pembelajaran Di Min Sukadamai Kota Banda Aceh. IImiah, 16, 23-42. 
